\title{
Direct Radioimmunoassay of Progesterone in Rat Serum
}

\author{
Yoshitaka TAKaHASHI, Yoshinisa HASEGAWA, ChIaki YAZAKI \\ AND MASAO IGARASHI
}

Department of Obstetrics and Gynecology, School of Medicine, Gunma University, Maebashi

\begin{abstract}
A direct method has been described which makes possible a specific assay of progesterone in rat serum without extraction.

Anti-progesterone serum was prepared in our laboratory by the immunization of three rabbits with 4-pregnen-3, 20-dione-3 CMO:BSA. This antiserum (Gunma OGP\#1) displayed little or no cross reaction with $20 \alpha$-dihydroprogesterone $(0.38 \%)$, pregnenolone $(0.44 \%), 17 \alpha$ hydroxypregnenolone $(<0.1 \%), 20 \beta$ hydroxyprogesterone $(2.4 \%), 17 \alpha$ hydroxyprogesterone $(2.88 \%)$ or deoxycorticosterone $(2.19 \%)$. The nonspecific inhibitory effect of serum was compensated for by adding progesterone-free serum to the standard curve tubes.

The sensitivity of this assay was $1.1 \mathrm{pg} /$ tube and serum progesterone could be measured by using as little as $1 \mu \mathrm{l}$ of serum.

The working range of the standard curve was $1.25-2560 \mathrm{ng} / \mathrm{ml}$.

Under the conditions of this assay ( $1 \mu \mathrm{l}$ of serum per tube), interference from steroid binding proteins did not affect the sensitivity, precision or reliability of the assay.

The intra-assay and inter-assay coefficients of variation were $5.5 \%$ and $8.7 \%$, respectively, and the assay values correlated well with those obtained by the extraction method $(\mathrm{R}=0.997, \mathrm{P}<0.001)$.

Analytical recovery indicates a close correlation between added and recovered progesterone concentrations $(\mathrm{R}=0.992, \mathrm{P}<0.001)$, and the recovery rate averaged $96 \%$.

Compared with the extraction method, the direct progesterone assay has the advantage of speed, precision and simplicity.

The method described is particularly suitable for routine assays of progesterone in rat serum.
\end{abstract}

Previously progesterone has been assayed only by bioassay, which was time-and money-consuming and had poor sensitivity and low accuracy.

Although development of the radioimmunoassay (RIA) of progesterone opened

Received April 3, 1985 a new era of reproductive endocrinology, initial RIA (van der Molen et al., 1965; Johansson, 1969; Lurie et al., 1970) had required complex extraction and purification steps, followed possibly by thin-layer or column chromatography. The availability of highly specific antisera has eliminated the purification step from many steroid RIAs 
(Furuyama et al., 1971; Dighe and Hunter, 1974; Riley et al., 1972).

However, there remains the problem of endogenous steroid hormone binding proteins.

Measurement of serum progesterone requires an extraction step with organic solvents to separate the progesterone from serum.

A direct method omitting extraction would save labor, time and the cost of assays.

Such a method has been proposed for several studies in animal and human serum (Haynes et al., 1980; Stupnicki, 1975; Stupnicki and Kula, 1982; Schanbacher, 1979; Mertens et al., 1983; Jurjens et al., 1975), but was found unsatisfactory for rat serum.

Progesterone concentrations in rat serum were higher $(5 \mathrm{ng}-50 \mathrm{ng} / \mathrm{ml})$ than in any other animals and men.

We were therefore to use a 200-fold dilution of rat serum ( $1 \mu \mathrm{l}$ of serum per tube) in this direct assay.

Under these assay conditions, interference from steroid hormone binding proteins did not affect the sensitivity, precision or reliability.

In this report, we have described a direct RIA of progesterone in rat serum which was simple, precise, time-saving and was free from the interference of steroid hormone binding proteins.

\section{Materials and Methods}

\section{Hormone Preparations}

Progesterone-3-(0-carboxymethyl) oximino-(2$\left[{ }^{125} \mathrm{I}\right]$ ) iodohistamine (IM 139, specific radioactivity $2000 \mathrm{Ci} / \mathrm{mmol})$ and $\left[1,2,6,7-{ }^{3} \mathrm{H}\right]$ progesterone (TRK 413 Batch 35, specific radioactivity $96 \mathrm{Ci}$ / mmol) were obtained from Amersham International Plc., Buckinghamshire., England.

4-pregnen-3,20-dione 3-CMO: BSA (Batch 2677; 29 moles steroid : mole BSA., $25 \mathrm{mgmQ}$ 2606) was purchased from Steraloids, INC.
WILTON, N. H.

Freund's complete adjuvant $\mathrm{H} \mathrm{Rv}$ (Lot No SDR 9705) was obtained from Wako Pure Chemical Industries, Ltd.

Progesterone, pregnenolone, $20 \alpha$ dihydroprogesterone, 20 $\beta$ hydroxyprogesterone, 17 $\alpha$ hydroxyprogesterone, 17 $\alpha$ hydroxypregnenolone, deoxycorticosterone, cortisol, testosterone, dihydrotestosterone, androstenedione, dehydroepiandrosterone, estradiol, estrone and cholesterol, were purchased from Sigma Chemical Co., St. Louis, U.S. A.

\section{Preparations of immunogen and antisera}

4-pregnen-3,20-dione was used to immunize three male Japanese white rabbits which were purchased from the Imai Experimental Animal Farm, Saitama.

Immunization was performed according to the method described by Vaitukaitis et al. (1971).

Three $\mathrm{mg}$ of the antigen was dissolved in 3 $\mathrm{ml}$ of $0.15 \mathrm{M} \mathrm{NaCl}$ and emulsified with $3.3 \mathrm{ml}$ complete Freund's adjuvant.

First, $1 \mathrm{mg} / 2 \mathrm{ml}$ antigen was administered i.c. at about 30 sites in each rabbit. The injections were repeated weekly for 6 weeks at a dose of $0.5 \mathrm{mg} / 2 \mathrm{ml}$.

Thereafter, booster injections were given at 2 week intervals for 6 weeks and at 4 week intervals 3 times. The increases in titer were monitored by small blood samples taken at $6-11$ days after each booster.

At the 7th month after the initial immunization, and 6 days after the last injection, the animals were bled through the carotid artery under light anesthesia. Collected sera were stored frozen at $-80^{\circ} \mathrm{C}$.

Then one $0.5 \mathrm{ml}$ portion was dissolved in $99.5 \mathrm{ml}$ of $0.05 \mathrm{M}$ EDTA-50 mM PBS (pH 7.5) and frozen at $-80^{\circ} \mathrm{C}$ in $0.4 \mathrm{ml}$ aliquots $(200$ fold dilution).

Out of 3 animals immunized, 1 died after the 5th immunization and 2 responded well and produced antisera of sufficiently high titer and specificity to be used in RIA.

One of the antisera (Gunma OGP\#1) was used throughout the study.

\section{Progesterone-free serum}

This was prepared by the method of Zarrow, Yochim and McCarthy (1964 a, b).

Adult male rats of the Wistar strain bred in our laboratory were used for these surgical 
operations.

Adrenalectomy and orchidectomy were performed under ether anaesthesia and 0.9\% saline was substituted for drinking water post-operatively in the case of these animals.

After one week of treatment, the rats were decapitated and examined for RIA of plasma progesterone.

These sera were suitable for progesterone-free serum when the concentration of progesterone was below $60-70 \mathrm{pg} / \mathrm{ml}$. This can be checked by a reference method (by a RIA involving extraction).

\section{Assay procedure}

a) Antiserum

One $0.4 \mathrm{ml}$ portion of 200 -fold diluted antiserum was diluted with $199.6 \mathrm{ml}$ of $0.5 \%$ NRSEDTA-PBS (pH 7.5).

The dilution required to bind 40 to $50 \%$ of ca $4000-5000 \mathrm{cpm}$ of ${ }^{125}$ I-progesterone was found to be $1: 100,000$.

b) Standard curve

From the stock solution of progesterone in methanol $(10 \mu \mathrm{g} / \mathrm{ml}), 100 \mu \mathrm{l}$ was added to 78.125 $\mathrm{ml}$ of $1 \%$ BSA-PBS.

This contained $12.8 \mathrm{ng}$ progesterone per $\mathrm{ml}$ and served as the working standard solution.

A series of consecutive two-fold dilutions was prepared so as to obtain the following concentrations: $2560,1280,640,320,160,80,40$, $20,10,5,2.5,1.25 \mathrm{pg} / 0.2 \mathrm{ml}$.

\section{c) Assay method}

In the direct RIA method, $200 \mu 1$ of assay buffer or standard solution ( $1.25 \mathrm{pg}-2560 \mathrm{pg} /$ tube), and $200 \mu \mathrm{l}$ of serum samples or progesteronefree serum which was diluted 200 -fold with assay buffer, were added to triplicate assay tubes and incubated with $200 \mu \mathrm{l}$ of diluted antiserum in $0.5 \%$ NRS $0.05 \mathrm{M}$ EDTA-PBS $(1: 100,000)$ for $24 \mathrm{hrs} 4^{\circ} \mathrm{C}$.

$100 \mu \mathrm{l}$ of ${ }^{125} \mathrm{I}$-labelled progesterone tracer (ca $4000 \mathrm{cpm}, 0.8 \mathrm{pg} /$ tube) was then added to all tubes and incubated at $4^{\circ} \mathrm{C}$ for $24 \mathrm{hrs}$.

$200 \mu \mathrm{l}$ of second antibody, diluted further in $0.05 \mathrm{M}$ EDTA-PBS, was finally added to all tubes except those for total count and incubated at $4^{\circ} \mathrm{C}$ for $48 \mathrm{hrs}$.

At the end of the third incubation, the tubes were centrifuged at $3000 \mathrm{rpm}$ for 30 minutes $\left(4^{\circ} \mathrm{C}\right)$ to separate the free from the bound tracer.

The supernatant was removed by decantation and the precipitates were counted in an Aloka
601 Automatic $\gamma$ counter.

d) Sample extraction

$0.5-0.8 \mathrm{ml}$ aliquots of rat serum samples were pipetted into $18 \times 110 \mathrm{~mm}$ glass test tubes and extracted by vortex mixing for $30 \mathrm{sec}$. with $5-6$ vol of ether.

After clear separation of the two phases, the lower phase was quick-frozen by immersing in a cold methanol bath $\left(-70^{\circ} \mathrm{C}\right)$.

The organic layer was decanted into $15 \times$ $105 \mathrm{~mm}$ glass tubes and evaporated with a centrifuging evaporator (Yamato Scientific Co., Ltd. Tokyo).

The dried residues of the extracted progesterone were dissolved in $0.5-0.8 \mathrm{ml}$ of assay buffer and then diluted 200-fold with assay buffer and transferred to assay tubes for RIA.

For calculation of the recovery after extraction, $0.5-0.8 \mathrm{ml}$ aliquots of control serum samples which contained $0.1 \mathrm{ml}$ of ${ }^{3} \mathrm{H}$-progesterone (ca $1000 \mathrm{dpm}, 1.5 \mathrm{pg} /$ tube) were extracted with 5-6 vol of ether.

The dried residues were dissolved in 0.5-0.8 $\mathrm{ml}$ of assay buffer and added to counting vials containing $10 \mathrm{ml}$ of scintillation fluid.

The radioactivity was counted for $5 \mathrm{~min}$.

\section{Rat estrous cycle}

A total of 46 mature female Wistar rats, weighing $250-300 \mathrm{~g}$, were housed under controlled temperature and lighting (lights on from 0500$1900 \mathrm{~h}$ ) and supplied with water and food at libitum.

Vaginal smears were taken daily, and only animals showing at least 2 regular 4-day cycles were used.

Rats were decapitated at $1800 \mathrm{hr}$ of each day of the estrous cycle and also at $0700 \mathrm{hr}, 1000 \mathrm{hr}$, $1600 \mathrm{hr}$ and $2000 \mathrm{hr}$ during proestrus, $1000 \mathrm{hr}$ and $1400 \mathrm{hr}$ during estrus.

Groups of four to eleven rats were used for each progesterone assay.

They were decapitated and blood was collected into $18 \times 100 \mathrm{~mm}$ tubes, and the serum was separated by centrifugation and stored at $-20^{\circ} \mathrm{C}$ until assayed.

\section{Results}

\section{Specificity of antiserum}

The specificity of the antiserum is documented in Table 1, which indicates the 
Table 1. Specificity on rabbit antiserum (Gunma OGP \#1) to progesterone 3-CMO-BSA conjugate.

\begin{tabular}{lc}
\hline \multicolumn{1}{c}{ Steroid } & $\begin{array}{c}\text { Percent } \\
\text { cross }\end{array}$ \\
\hline Progesterone & 100 \\
20 $\alpha$-Dihydroprogesterone & 0.38 \\
20 $\beta$-Hydroxyprogesterone & 2.4 \\
$17 \alpha$-Hydroxyprogesterone & 2.88 \\
Pregnenolone & 0.44 \\
17 $\alpha$-Hydroxypregnenolone & $<0.1$ \\
Cortisol & $<0.01$ \\
Deoxycorticosterone & 2.19 \\
Androstenedione & $<0.1$ \\
Dehydroepiandrosterone & $<0.1$ \\
Testosterone & $<0.1$ \\
Dihydrotestosterone & $<0.01$ \\
17 $\beta$-Estradiol & $<0.01$ \\
Estrone & $<0.1$ \\
Cholesterol & $<0.01$ \\
\hline
\end{tabular}

percentage of cross-reactivity of other steroids with the antiserum, estimated from the values at $50 \%$ displacement of tracer binding.
The other steroids tested showed little or no detectable cross reaction.

Interference in hormone-antiserum binding by serum.

Fig. 1 and Table 2 demonstrate the inhibitory effect of serum on the binding of progesterone to antiserum.

It follows from the data that the greater the serum increase (from $1 \mu \mathrm{l}$ to $8 \mu \mathrm{l}$ of serum), the lower the zero-dose binding and assay sensitivity.

The slopes of the displacement curves generated by serial dilutions of progesteronefree serum were consistently parallel to that of the standard.

\section{Sensitivity}

Fig. 2 shows typical standard curves of the direct method and of the extraction method.

The means for the different progesterone concentrations obtained in 5 assays are on a straight line in both methods (log-logit

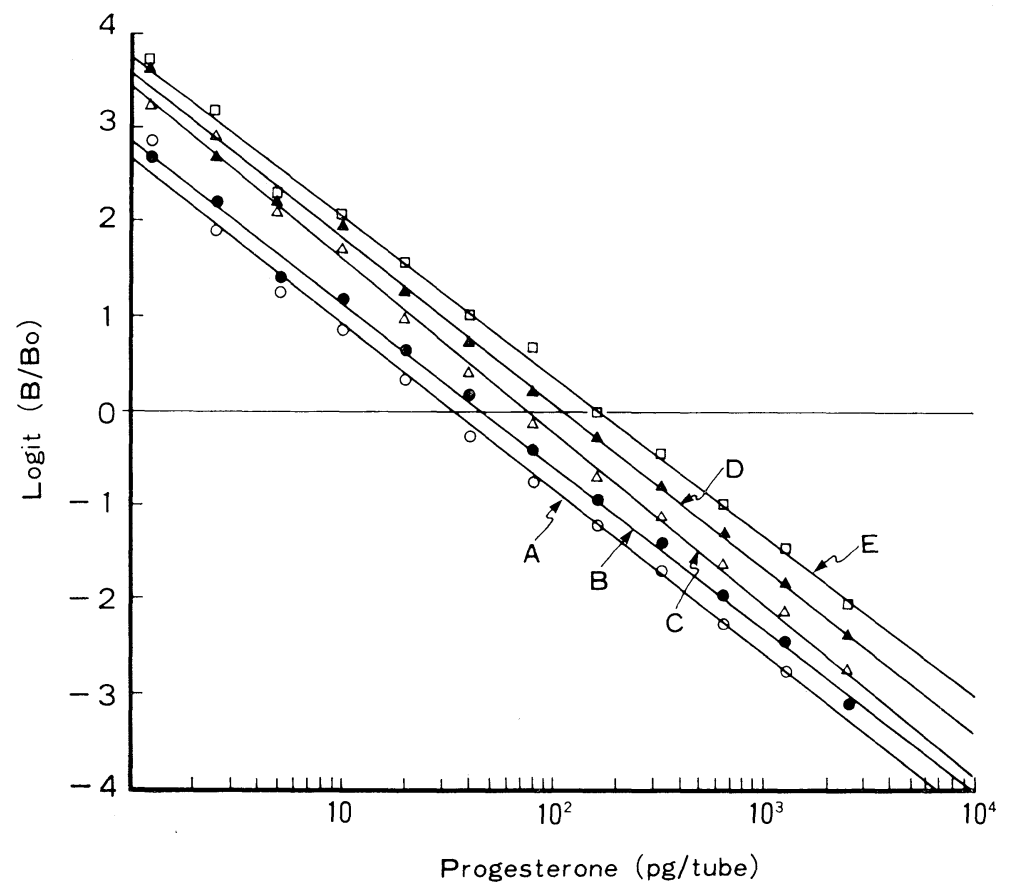

Fig. 1. Inhibition curves for a direct assay of progesterone in various amounts of rat serum. The direct method was carried out in the following system : $200 \mu \mathrm{l}$ of $1 \%$ BSA-PBS (A) or 200 $\mu l$ of progesterone-free serum diluted 200-fold (B : $1 \mu \mathrm{l}$ of serum/tube), 100-fold (C: $2 \mu \mathrm{l}$ of serum /tube), 50 -fold (D : $4 \mu \mathrm{l}$ of serum/tube) and 25-fold (E: $8 \mu \mathrm{l}$ of serum/tube) with $1 \%$ BSA-PBS, $200 \mu 1$ of standard dissolved in $1 \%$ BSA-PBS $(1.25 \mathrm{pg}-$ $2560 \mathrm{pg} /$ tube), $200 \mu \mathrm{l}$ of diluted antiserum in $0.5 \%$ NRS $0.05 \mathrm{M}$ EDTA-PBS and $100 \mu 1$ of ${ }^{125}$ I-labelled progesterone. 
Table 2. Parameters for the direct RIA of progesterone in various amounts of rat serum.

\begin{tabular}{lccccc}
\hline & \multicolumn{5}{c}{ Amount of serum per tube } \\
\cline { 2 - 6 } & $\mathrm{A}$ & $\mathrm{B}$ & $\mathrm{C}$ & $\mathrm{D}$ & $\mathrm{E}$ \\
& $0 \mu \mathrm{l}$ & $1 \mu \mathrm{l}$ & $2 \mu \mathrm{l}$ & $4 \mu \mathrm{l}$ & $8 \mu \mathrm{l}$ \\
\hline Zero-dose binding (Bo/T) & & & & & \\
$\quad$ Mean (\%) & 48.9 & 46.8 & 44.7 & 43.0 & 39.6 \\
S. D. & 1.1 & 0.6 & 0.9 & 0.7 & 0.3 \\
Sensitivity (pg/tube) & 0.7 & 0.9 & 1.9 & 2.3 & 3.0 \\
$\quad$ Mean (pg/tube) & $0.5-0.9$ & $0.8-1.0$ & $1.6-2.2$ & $1.9-2.7$ & $2.6-3.5$ \\
95\% limit & & & & & \\
Midrange concentration & & & & & \\
$\quad$ (X-intercept, "ED-50") & 33.5 & 45.4 & 75.5 & 107.2 & 163.6 \\
Mean (pg/tube) & $29.3-38.5$ & $41.9-49.3$ & $69.1-82.6$ & $95.9-119.7$ & $142.2-181.9$ \\
95\% limit & -1.743 & -1.714 & -1.824 & -1.754 & -1.691 \\
Slope (decimal logit-log) & 0.043 & 0.026 & 0.030 & 0.035 & 0.031 \\
S. E. & & & & & \\
\hline
\end{tabular}
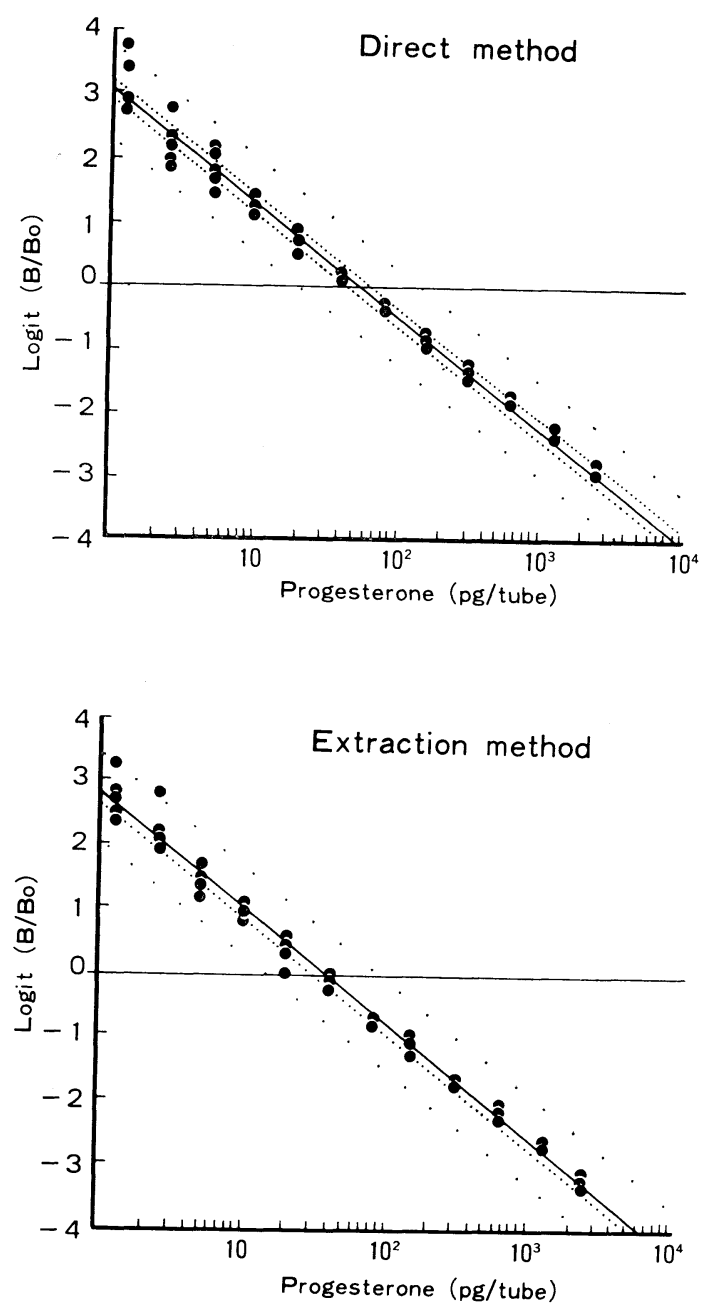

paper).

Some assay conditions and mean assay parameters for both methods are summarized in Table 3.

It follows from the data presented that $1 \mu$ of serum (serum standard) did not affect the sensitivity, as shown in Fig. 2.

Under these assay conditions, the standard curve for the direct method exhibited adequate sensitivity (a reasonably steep slope for the standard curve) throughout the range $1.25-2560 \mathrm{pg} /$ tube.

As summarized in Table 3 , the assay sensitivity, based on the $95 \%$ confidence limit of the mean of 5 replicate tests for the zero standard, was $1.1 \mathrm{pg} /$ tube $(1.1 \mathrm{ng} / \mathrm{ml}$ serum $)$ and $0.8 \mathrm{pg} /$ tube $(0.8 \mathrm{ng} / \mathrm{ml}$ serum $)$ for the direct and extraction method, respectively.

Fig. 2. Mean standard curves for the direct method and for the extraction method. The direct method was carried out in the following system : $200 \mu \mathrm{l}$ of assay buffer (1\% BSA-PBS) or standard solution (1.25-2560 pg/tube), $200 \mu \mathrm{l}$ of serum samples or progesterone free serum which was diluted ( $1 \mu \mathrm{l}$ of serum/tube), $200 \mu \mathrm{l}$ of diluted antiserum $(1: 100,000)$ and $100 \mu \mathrm{l}$ of ${ }^{125}$ I-labelled progesterone. 
Table 3. Assay parameters for the direct and the extraction method. Note. The assay sensitivity is based on the $95 \%$ confidence limit of the mean of 5 replicate tests for the zero standard.

\begin{tabular}{lcc}
\hline & $\begin{array}{c}\text { Direct } \\
\text { method }\end{array}$ & $\begin{array}{c}\text { Extraction } \\
\text { method }\end{array}$ \\
\hline Amount of serum ( $\mu \mathrm{l} /$ tube) & 1 & 0 \\
Zero-dose binding (Bo/T) & & \\
Mean (\%) & 54.6 & 57.7 \\
S. D. & 2.4 & 2.2 \\
Sensitivity & 1.1 & 0.8 \\
$\quad$ Mean (pg/tube) & $0.9-1.4$ & $0.6-1.0$ \\
95\% limit & & \\
Midrange concentration & & \\
(X-intercept, “ED-50") & & 35.4 \\
Mean (pg/tube) & 51.6 & $31.6-39.6$ \\
95\% limit & $45.7-58.3$ & \\
Range of applications & & \\
(pg/tube) & $1.25-2560$ & $1.25-2560$ \\
Slope (decimal logit-log) & -1.756 & -1.769 \\
S. E. & 0.043 & 0.039 \\
\hline
\end{tabular}

The coefficient of variation at each point of the standard curve varied from 5 to $10 \%$ and 2 to $11 \%$ for the direct and extraction method, respectively.

\section{Precision}

The intra- and inter-assay variance was evaluated by triplicate measurements of the same assay and in five different assays.

Specimens were analyzed in triplicate by the direct RIA method, and single extracts of specimens were analyzed in triplicate by the extraction RIA.

In triplicate determinations of 12 samples in the same assay, which values ranged from 17.1 to $1177.5 \mathrm{ng} / \mathrm{ml}$, the coefficient of variation was $5.5 \%$ for both methods (Table 4).

Interassay variance for both methods is shown in Table 5.

In five different assays, the coefficient of variation was $8.7 \%$ and $6.7 \%$ for the direct and extraction method, respectively.
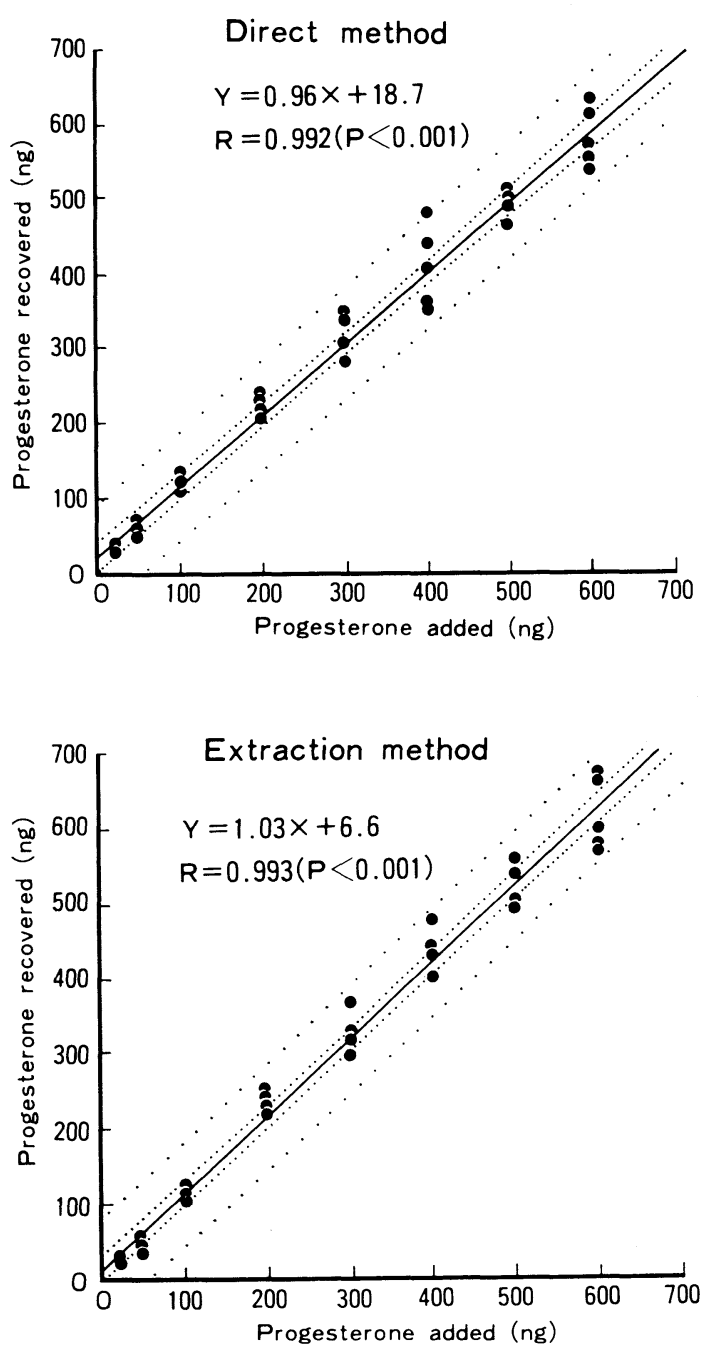

Fig. 3. The recovery of various amounts of progesterone added to rat serum. These data were collected on five separate days with the extraction method on a single extract and on five separate days with the direct method.

Accuracy

To assess analytical recovery, we measured progesterone in 8 samples by both the direct and the extraction method.

Fig. 3 shows the linear regression line $(\mathrm{Y}=\mathrm{AX}+\mathrm{B})$ for the correlation of added versus recovered progesterone quantities. 
As summarized in Fig. 3, the recovery for the direct method averaged $96 \%$, while the mean recovery for the extraction method was $103 \%$.

Comparison of the direct method with the extraction method for progesterone in rat serum

We measured progesterone in 12 specimens from rats ranging from $10 \mathrm{ng} / \mathrm{ml}$ to
$1280 \mathrm{ng} / \mathrm{ml}$ serum.

As shown in Fig. 4, results obtained by both methods agreed well with each other $(\mathrm{R}=0.997, \mathrm{P}<0.001)$.

Peripheral serum levels of progesterone at various times during the estrous cycle.

Serum progesterone concentrations, which were assayed by direct and extraction RIA

Table 4. Intra-assay precision of progesterone determination. The intra-assay variance was evaluated by three determinations of the same samples in the same assay.

\begin{tabular}{|c|c|c|c|c|c|c|c|c|}
\hline & & & Proge & terone concent & ration $(n$ & & & \\
\hline & & & ct metho & & & ractio & method & \\
\hline & Mean & SD & $\mathrm{CV}(\%)$ & No. of tubes & Mean & $\mathrm{SD}$ & CV (\%) & No. of tubes \\
\hline 1 & 22.1 & 0.7 & 2.9 & 3 & 17.1 & 0.6 & 3.6 & 3 \\
\hline 2 & 52.6 & 3.8 & 7.3 & 3 & 47.8 & 5.2 & 10.9 & 3 \\
\hline 3 & 85.8 & 5.4 & 6.3 & 3 & 69.6 & 3.8 & 5.5 & 3 \\
\hline 4 & 151.4 & 12.0 & 7.9 & 3 & 120.4 & 9.7 & 8.1 & 3 \\
\hline 5 & 253.3 & 5.7 & 2.2 & 3 & 233.9 & 10.9 & 4.7 & 3 \\
\hline 6 & 360.3 & 19.3 & 5.4 & 3 & 332.2 & 11.6 & 3.5 & 3 \\
\hline 7 & 458.2 & 23.6 & 5.2 & 3 & 455.8 & 25.6 & 5.6 & 3 \\
\hline 8 & 523.7 & 35.0 & 6.7 & 3 & 511.5 & 6.0 & 1.2 & 3 \\
\hline 9 & 639.3 & 68.3 & 10.7 & 3 & 595.2 & 11.6 & 1.9 & 3 \\
\hline 10 & 725.8 & 31.7 & 4.4 & 3 & 769.6 & 61.0 & 7.9 & 3 \\
\hline 11 & 851.4 & 43.6 & 5.1 & 3 & 850.6 & 60.9 & 7.2 & 3 \\
\hline 12 & 1098.0 & 24.4 & 2.2 & 3 & 1177.5 & 65.8 & 5.6 & 3 \\
\hline
\end{tabular}

Table 5. Inter-assay precision of progesterone determination. The inter-assay coefficient of variation was evaluated by triplicate measurements in five different assays using the same samples.

\begin{tabular}{|c|c|c|c|c|c|c|c|c|}
\hline & \multicolumn{8}{|c|}{ Progesterone concentration $(\mathrm{ng} / \mathrm{ml})$} \\
\hline & \multicolumn{4}{|c|}{ Direct method } & \multicolumn{4}{|c|}{ Extraction method } \\
\hline & Mean & SD & CV (\%) & $\mathbf{N}$ & Mean & SD & CV $(\%)$ & $\mathrm{N}$ \\
\hline 1 & 23.4 & 1.5 & 0.6 & 5 & 17.8 & 1.5 & 8.2 & 5 \\
\hline 2 & 53.9 & 2.7 & 4.9 & 5 & 43.9 & 3.8 & 8.6 & 5 \\
\hline 3 & 82.5 & 6.2 & 7.5 & 5 & 67.9 & 3.5 & 5.2 & 5 \\
\hline 4 & 143.6 & 6.3 & 4.4 & 5 & 129.6 & 7.5 & 5.8 & 5 \\
\hline 5 & 245.4 & 8.1 & 3.3 & 5 & 240.2 & 9.6 & 4.0 & 5 \\
\hline 6 & 337.8 & 24.4 & 7.2 & 5 & 343.7 & 22.3 & 6.5 & 5 \\
\hline 7 & 429.1 & 53.2 & 12.4 & 5 & 453.1 & 25.6 & 5.7 & 5 \\
\hline 8 & 507.6 & 19.8 & 3.9 & 5 & 531.1 & 30.3 & 5.7 & 5 \\
\hline 9 & 582.6 & 81.2 & 13.9 & 5 & 632.4 & 46.9 & 7.4 & 5 \\
\hline 10 & 762.7 & 107.8 & 14.1 & 5 & 779.8 & 57.4 & 7.4 & 5 \\
\hline 11 & 829.4 & 65.3 & 7.9 & 5 & 861.4 & 64.3 & 7.5 & 5 \\
\hline 12 & 1157.0 & 280.1 & 24.2 & 5 & 1315.1 & 108.3 & 8.2 & 5 \\
\hline
\end{tabular}



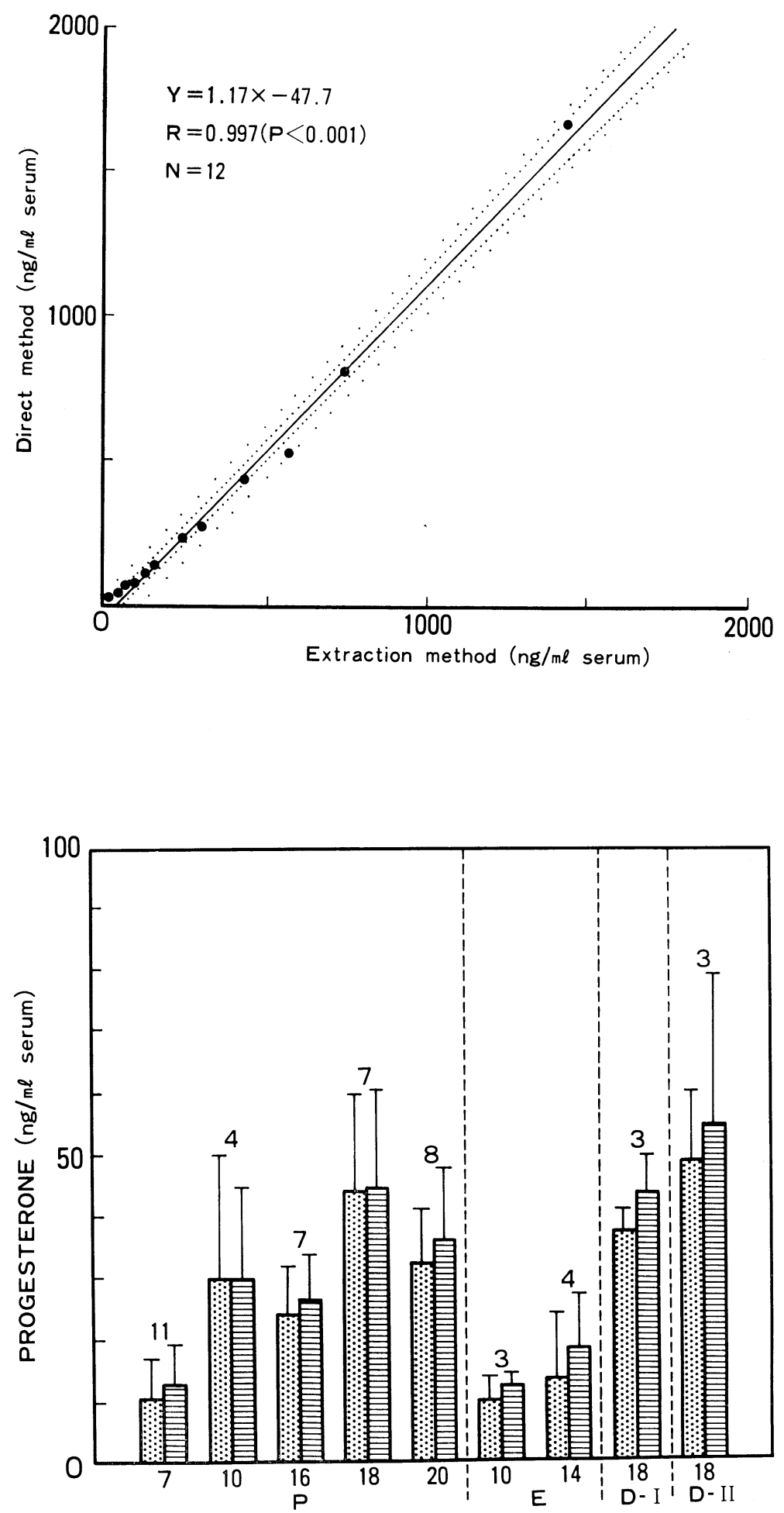

Fig. 4. Comparison of the direct method and the extraction method for progesterone in serum from rat.

Fig. 5. Mean concentrations of serum progesterone during the 4-day estrous cycle of the rat, which was assayed by direct 貝 and extraction 网 methods. Bars indicate standard deviation of mean, and numbers on top indicate number of rats from which blood samples were collected. 


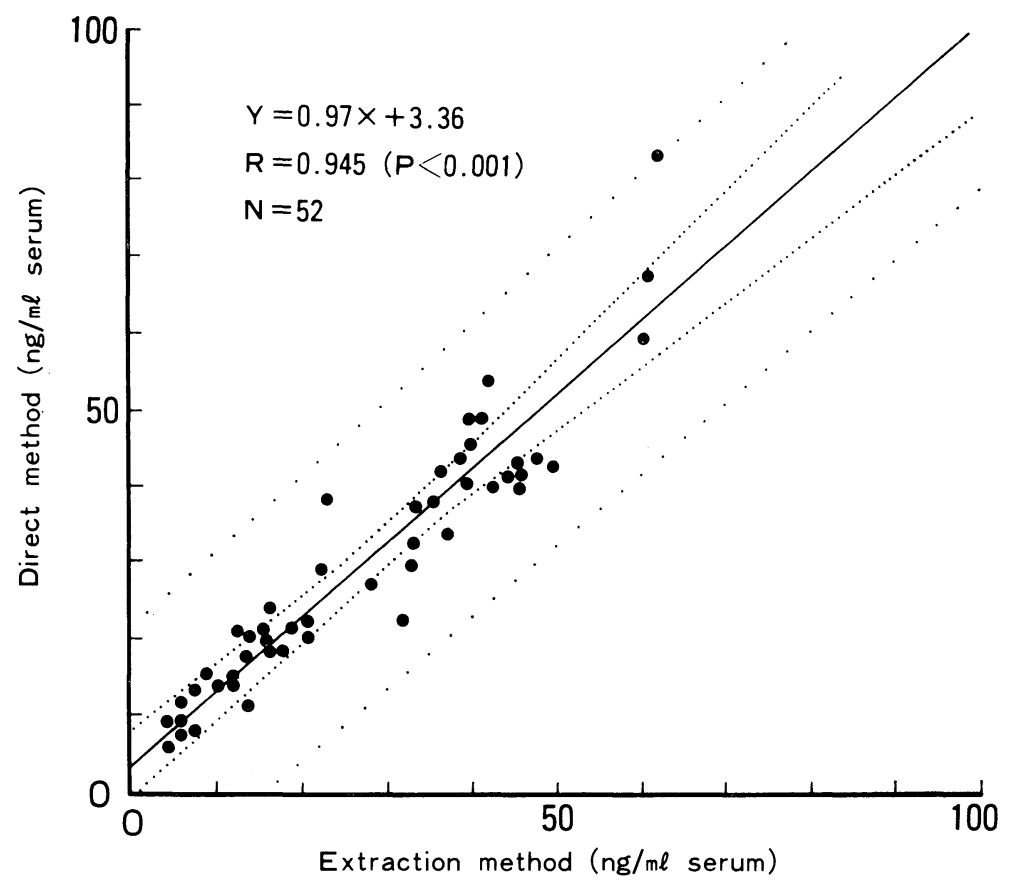

Fig. 6. Correlation between progesterone concentration in rat serum samples as estimated by the direct method and extraction method. methods, throughout the estrous cycle in the rats are illustrated in Fig. 5.

The preovulatory rise in progesterone was observed at $1000 \mathrm{hr}$ of proestrus, with a peak at $1800 \mathrm{hr}(44.0 \pm 15.9 \mathrm{ng} / \mathrm{ml}$, and $44.7 \pm 15.8 \mathrm{ng} / \mathrm{ml}$ in the extraction and direct method, respectively), and then returned to the base level at noon of estrus.

There was a rise in the progesterone concentration late on diestrus-I to $37.5 \pm$ $3.6 \mathrm{ng} / \mathrm{ml}$ (extraction method) and $43.8 \pm$ $6.0 \mathrm{ng} / \mathrm{ml}$ (direct method) at $1800 \mathrm{hr}$.

A further rise was found late in diestrusII to $48.8 \pm 11.7 \mathrm{ng} / \mathrm{ml}$ (extraction method) and $54.6 \pm 24.8 \mathrm{ng} / \mathrm{ml}$ (direct method) at $1800 \mathrm{hr}$.

A comparison of the direct method and the extraction method for progesterone in serum from rats throughout the estrous cycle is shown in Fig. $6(\mathrm{R}=0.945, \mathrm{P}<$ 0.001).

\section{Discussion}

Ideally, it is desirable to perform progesterone RIA directly on serum; however, interference with serum constituents such as steroid binding proteins provide major obstacles.

These nonhormonal components in serum have been shown to exert nonspecific effects in a direct progesterone RIA.

In the direct RIA in this paper, steroidfree serum was previously added to the standard curve tubes in order to circumvent these nonspecific effects.

These methods had been reported by other workers (Haynes et al., 1980 ; Stupnicki and Kula, 1982; Stupnicki, 1975; Ogihara et al., 1977).

In the direct RIA method mentioned in our report, the components in serum inhibited ${ }^{125}$ I-progesterone to antiserum in a 
concentration-dependent manner.

The slope of the displacement curves generated by serial dilutions of progesteronefree serum were consistently parallel to that of the standard, indicating that the components causing the displacement of ${ }^{125} \mathrm{I}-$ labelled progesterone from antibody was immunologically identical to progesterone.

Since the progesterone concentrations in the estrous cycle of the rat vary from $5 \mathrm{ng}$ to $50 \mathrm{ng} / \mathrm{ml}$ (Butcher et al., 1974; Smith et al., 1975, Nequin et al., 1975; Kalra and Kalra, 1974), which is higher than for any other animals, e.g., ovine $0.2 \mathrm{ng}-4.0 \mathrm{ng} / \mathrm{ml}$ (Pant et al., 1977)., bovine, $0 \mathrm{ng}-8.5 \mathrm{ng} / \mathrm{ml}$ (Stupnicki 1975), guinea-pig, $0.5 \mathrm{ng}-3.2 \mathrm{ng} /$ $\mathrm{ml}$ (Blatchley et al., 1976), and also human, $0.4 \mathrm{ng}-13.0 \mathrm{ng} / \mathrm{ml}$ (Moghissi et al., 1972), we are able to use a 200 -fold dilution of serum (only $1 \mu \mathrm{l}$ of serum per tube) from rat.

Under these assay conditions, the standard curve for the direct method exhibits adequate sensitivity throughout the range $1.25 \mathrm{ng}-2560 \mathrm{ng} / \mathrm{ml}$ serum.

The specificity of antiserum to steroids is dependent on the site through which the steroid molecule is conjugated to protein (Niswender, 1973).

Our results have confirmed the specificity to be expected of antiserum raised to progesterone 3-CMO: BSA conjugates.

The specificity of our antiserum with respect to pregnenolone ( $\%$ cross reaction: $0.44 \%$ ) was much better than reported by Scarisbrick (1975; \% cross reaction 37\%) and Niswender (1973;\% cross reaction $13.3 \%)$.

For 20 $\beta$-hydroxyprogesterone antiserum (Niswender, 1973) at $0.3 \%, 17 \alpha$ hydroxyprogesterone antiserum (Scarisbrick, 1975) at $1.2 \%$ and deoxycorticosterone antiserum (Niswender, 1973) at $1.6 \%$ were somewhat better than ours with $2.40 \%, 2.88 \%$ and $2.19 \%$, respectively.

Though the cross-reaction of $17 \alpha$-hydroxyprogesterone is relatively high $(2.88 \%)$, the concentration of this steroid varies between only $2 \mathrm{ng}$ and $3 \mathrm{ng} / \mathrm{ml}$ (Shaikh and

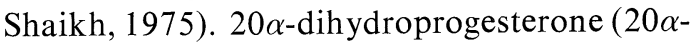
DHP) is present in much higher concentrations than progesterone in rat serum (e.g., Nequin et al., 1975, peak progesterone concentrations in peripheral plasma were $40 \mathrm{ng}-$ $60 \mathrm{ng} / \mathrm{ml}$, whereas peak $20 \alpha$-DHP levels were about $230 \mathrm{ng} / \mathrm{ml}$.), but its cross reactivity was only slight $(0.38 \%)$.

Since our antibodies have high specificity for progesterone, other circulating steroids should not interfere with the direct assay technique.

The present direct assay meets all the requirements of specificity, reliability, sensitivity and practicability.

When compared with methods involving extraction, the direct assay gave very similar results $(\mathrm{R}=0.997, \mathrm{P}<0.001$; Fig. 4) and proved especially suitable for routine work.

The concentrations of serum progesterone obtained by direct RIA throughout the estrous cycle in the rats were in agreement with other reports (Smith et al., 1975; Nequin et al., 1975; Kalra and Kalra., 1974; Butcher et al., 1974), except on the day of diestrus-II.

It is reported that the progesterone level rose dramatically on the afternoon and evening of proestrus, and slightly on dietrusI.

Although the progesterone concentration on dietrus-II was reported in the range of $3 \mathrm{ng}-15 \mathrm{ng} / \mathrm{ml}$ serum (Butcher et al., 1974, Smith et al., 1975), our data displayed high levels of progesterone on diestrus-II to $48.8 \pm 11.7 \mathrm{ng} / \mathrm{ml}$ (extraction method) and $54.6 \pm 24.8 \mathrm{ng} / \mathrm{ml}$ (direct method) at $1800 \mathrm{hr}$ on diestrus-II.

The reasons for these discrepancies are unclear, but are probably related to the fact that the adrenal gland contributes to the pool of circulating progesterone, especially under conditions of stress (Barraclough et al., 1971; Feder et al., 1971; Feder et al., 1968).

Because it does not require expensive and 
dangerous extraction solvents, the assay described herein provides a convenient and economical procedure for assessing the physiological condition of the rat.

\section{References}

Bärraclough, C. A., R. Collu, R. Massa and L. Martini (1971). Temporal interrelationships between plasma LH, ovarian secretion rates and peripheral plasma progestin concentrations in the rat: Effects of nembutal and exogenous gonadotropins. Endocrinology 88, 1437-1447.

Blatchley, F. R., B. T. Donovan and M. B. TerHaar (1976). Plasma progesterone and gonadotrophin levels during the estrous cycle of the guinea pig. Biol. Reprod. 15, 29-38.

Buther, R. L., W. E. Collins and N. W. Fugo (1974). Plasma concentration of LH, FSH, prolactin, progesterone and estradiol-17 $\beta$ througout the 4-day estrous cycle of the rat. Endocrinology 94, 1704-1708.

Dighe, K. K. and W. M. Hunter (1974). A solidphase radioimmunoassay for plasma progesterone. Biochem. J. 143, 219-231.

Feder, H. H., K. Brown-Grant and C. S. Corker (1971). Pre-ovulatory progesterone, the adrenal cortex and the 'critical period' for luteinizing hormone release in rats. J. Endcrinol. 50, 2939.

Feder, H. H., J. A. Resko and R. W. Goy (1968). Progesterone levels in the arterial plasma of pre-ovulatory and ovariectomized rats. J. Endocrinol. 41, 563-569.

Furuyama, S. and C. A. Nugent (1971). A radioimmunoassay for plasma progesterone. Steroids. 17, 663-674.

Haynes, S. P., Jo M. Corcoran, C. J. Eastman and F. A. Doy (1980). Radioimmunoassay of progesterone in unextracted serum. Clin. Chem. 26, 1607-1609.

Johansson, E. D. B. (1969). Progesterone levels in perpheral plasma during the luteal phase of the normal phase of the normal human menstrual cycle measured by a rapid competitive protein binding technique. Acta. Endocrinol. 61, 592-606.

Jurjens, H., J. J. Pratt and M. G. Woldring (1975). Radioimmunoassay of plasma estradiol without extraction and chromatography. $J$. Clin. Endocrinol. Metab. 40, 19-25.
Kalra, S. P. and P. S. Kalra (1974). Temporal interrelationships among circulating levels of estradiol, progesterone and $\mathrm{LH}$ during the rat estrous cycle: Effects of exogenous progesterone. Endocrinology 95, 1711-1718.

Lurie, A. O. and R. J. Patterson (1970). Progesterone in nonpregnancy plasma. Clin. Chem. 16, 856-860.

Mertens, R., R. J. Liedtke and J. D. Batjer (1983). Evaluation of a radioimmunoassay for estradiol in unextracted serum. Clin. Chem. 29, 19611963.

Moghissi, K. S., F. N. Syner and T. N. Evans (1972). A composite picture of the menstrual cycle. Am. J. Obstet. Gynecol. 114, 405-416.

Nequin, L. G., J. Alvarez and N. B. Schwartz (1975). Steroid control of gonadotropin release. J. Steroid Biochem. 6, 1007-1012.

Niswender, G. D. (1973). Influence of the site of conjugation on the specificity of antibodies to progesterone. Steroids. 22, 413-424.

Ogihara, T., K. Iinuma, K. Nishi, Y. Arakawa, A. Takagi, K. Miyai and Y. Kumahara. (1977). A non-chromatographic non-extraction radioimmunoassay for serum aldosterone. $J$. Clin. Endocrinol. Metab. 45, 726-731.

Pant, H. C., C. R. N. Hopkinson and R. J. Fitzpatrick (1977). Concentration of estradiol, progesterone, luteinizing hormone and folliclestmulating hormone in the estrous cycle. $J$. Endocrinol. 73. 247-255.

Riley, W. J., E. R. Smith, D. M. Robertson and A. E. Kellie. (1972). The formation of steroidBSA antigens via a C-6 $\beta$-carboxymethyl substituent. J. Steroid Biochem. 3, 357-367.

Scarisbrick, J. J. and E. H. D. Cameron (1975). Radioimmunoassay of progesterone: Comparison of $\left[1,2,6,7-{ }^{3} \mathrm{H}_{4}\right]$-progesterone and progesterone-[ $\left.{ }^{125} \mathrm{I}\right]$-iodohistamine radioligands. J Steroid Biochem. 6, 51-56.

Schnbacher, B. D. (1979). Radioimmunoassay of ovine and bovine serum progesterone without extraction and chromatography. Endocr. Res. Commun. 6, 265-277.

Shaikh, A. A. and S. A. Shaikh (1975). Adrenal and ovarian steroid secretion in the rat estrous cycle temporarily related to gonadotropins and steroid levels found in peripheral plasma. Endocrinology 96, 37-44.

Smith, M, S., M. E. Freeman and J. D. Neil. (1975). The control of progesterone secretion during the estrous cycle and early pseudopregnancy in the rat: prolactin, gonadotropin 
and steroid levels associated with rescue of the corpus luteum of pseudopregnancy. Endocrinology 96, 219-226.

Stupnicki, R. and E. Kula. (1982). Direct radioimmunoassay of progesterone in human plasma. Endocrinologie 80, 1-7.

Stupnicki, R. (1975). Direct radioimmunoassay of progesterone in plasma of farm animals. Endocrinologie 66, 145-151.

Vaitukaitis, J., J. B. Robbins, E. Nieschlag and G. T. Ross. (1971). A method for producing specfic antisera with small doses of immunogen. J. Clin. Endocrinol. Metab. 33, 988-991.

van der Molen, H. J. and D. Creen. (1965). Determination of progesterone in human peri- pheral blood using gas-liquid chromatography with electron capture detection. J. Clin. Endocrinol. Metab. 25, 1625-1639.

Zarrow, M. X., J. M. Yochim and J. L. McCarthy. (1964 a) The androgens. In: Experimental Endocrinology. (M. X. Zarrow, J. M. Yochim, J. L. McCarthy and R. C. Sanborn ed.), Academic Press, New York and London. pp. 136137.

Zarrow, M. X., J. M. Yochim and J. L. McCarthy (1964 b). The adrenal corticoids. In: Experimental Endocrinology. (M. X. Zarrow, J. M. Yochim, J. L. McCarthy and R. C. Sanborn ed.). Academic Press, New York and London. pp. 194-196. 